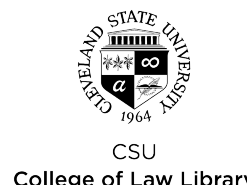

Cleveland State University

College of Law Library

\title{
EngagedScholarship@CSU
}

\section{Cochlear Implants and the Claims of Culture: A Response to Lane and Grodin}

Dena S. Davis

Cleveland State University, d.davis@csuohio.edu

Follow this and additional works at: https://engagedscholarship.csuohio.edu/fac_articles

Part of the Bioethics and Medical Ethics Commons

How does access to this work benefit you? Let us know!

\section{Original Citation}

Dena S. Davis, Cochlear Implants and the Claims of Culture: A Response to Lane and Grodin, 7 Kennedy Institute of Ethics Journal 253 (1997)

This Response or Comment is brought to you for free and open access by the Faculty Scholarship at EngagedScholarship@CSU. It has been accepted for inclusion in Law Faculty Articles and Essays by an authorized administrator of EngagedScholarship@CSU. For more information, please contact research.services@law.csuohio.edu. 


\title{
Cochlear Implants and the Claims of Culture? A Response to Lane and Grodin
}

\begin{abstract}
Because I reject the notion that physical characteristics constitute cultural membership, I argue that, even if the claim were persuasive that deafness is a culture rather than a disability, there is no reason to fault hearing parents who choose cochlear implants for their deaf children.
\end{abstract}

$\mathrm{L}$

ET ME BEGIN BY expressing my gratitude to Harlan Lane and Michael Grodin (1997) for their provocative and hard-hitting article. By positing a situation in which cochlear implants are riskfree and effective, they have constructed the strongest case possible for the use of such implants and thus have challenged themselves to make the most robust and uncompromising argument for the position that DEAF people are not disabled, but rather are members of a linguistic/cultural minority, and that parents act wrongly when they seek to convert deaf babies into hearing ones.

I will respond under three headings.

\section{IS DEAFNESS IS A DISABILITY?}

I cannot accept the claim that deafness is not to be perceived as a disability. The DEAF-WORLD of which the authors speak has created a rich and unique culture, and I am happy to assent to the claim that that culture is qualitatively, though not quantitatively, equal to that of the hearing world. It also is true that a great deal of what "disables" the deaf in our present world is socially constructed and could be substantially ameliorated by a more caring majority. But there is a difference between valuing the culture that the DEAF-WORLD has built and equating deafness with culture.

One of the defining differences between culture and disability is the option that human adults have to choose the extent to which they iden- 
tify with and participate in their culture. As the authors state, many people who are physically deaf are not members of the DEAF-WORLD (p. 233). Some hearing people are more at home in the DEAF-WORLD and more fluent in American Sign Language (ASL) than are many deaf people (Cohen 1995). Despite the many positive aspects of the DEAF-WORLD and despite the fact that DEAF and deaf people may, on average, lead lives as happy and productive as those of hearing people, I maintain that the inability to hear is a deficit, a disability, a lack of perfect health. A hearing person has a choice about whether to participate in DEAF culture, by learning ASL, attending social and cultural events, and so on. A nonhearing person, however, is irrevocably cut off from large areas of the hearing world. Even if I were to follow Lane and Grodin's generous example and posit an ideal educational environment for the deaf, most prelingually deafened persons would not be able to communicate effectively orally, with obvious social and vocational consequences. (I can anticipate an obvious response, that hearing people are equally disadvantaged because they can never be fully accepted in the DEAF-WORLD. But if that is true, it is because DEAF people are prejudiced against them, not because they are disabled from learning the necessary skills.)

\section{IS CULTURAL MEMBERSHIP PHYSIOLOGICALLY DETERMINED?}

I reject the notion that physical characteristics, hereditary or congenital, constitute cultural membership. Culture, the "body of customary beliefs, social forms, and material traits constituting a distinct complex of tradition of a racial, religious, or social group" (Webster's International Dictionary 1993), is passed on by people, not by genes. A child born into an Ashkenazic Jewish family, for example, partakes of that culture because her parents pass it on to her, in exactly the same way as they would pass it on to a child whom they adopted at birth (or as an embryo). Should this couple happen to have both a biological child and an adopted one, they would not consider one child to be "more" Jewish than the other. This is as silly as saying that Madeleine Albright is "really" Jewish. The opposite notion seems to me deeply racist and genetically determinist.

There are, of course, some counterexamples to my claim, as Lane and Grodin point out. In one type of counterexample, one acknowledges that a white couple raising an African-American child has an obligation to give the child a clear and proud sense of her black identity because, whatever they do, the child will be treated by others as a black person and therefore she needs a proud racial identity as a buffer against racism. In 
another type of counterexample, one might argue that a child with, say, an Italian genetic ancestry should know something about his parents' and grandparents' culture, feel proud of the accomplishments of his ancestors, and so forth. But neither of these arguments fits the situation of a deaf child born to hearing parents. Deaf children who are fitted with perfect cochlear implants will not be treated by others as deaf, and children of hearing parents obviously do not have deaf ancestors.

My point is that even if I were to accept the claim that deafness is a culture rather than a disability and even if there were no downsides to being deaf, there is no reason to fault hearing parents who, reasonably enough, prefer to have children who share their language and cultureand those of their siblings-and who do not require huge investments of parental resources to learn sign language, to pay for special schools and equipment, and so on.

\section{PRESERVATION OF MINORITY CULTURES}

Lane and Grodin raise the question of whether, since the "preservation of minority cultures is a good," parents have an ethical obligation not to choose cochlear implants for their nonhearing child, because converting their child from deaf-and therefore potentially DEAF-to hearing diminishes the population strength of the DEAF-WORLD. I perceive three arguments against this claim.

First, even if deafness is a culture rather than a disability, I think that the authors are, quite simply, asking too much. Raising a DEAF child well requires an enormous commitment of time, money, and energy. Parents, who usually are not expecting their new baby to be deaf, must learn ASL quickly in order to communicate with their child early so that language is mastered at the appropriate developmental stages. In addition, they may need to pull up stakes and relocate to a community that can offer the appropriate services. If they adopt the DEAF values that the authors describe, integration of their child into hearing schools will be "anathema," and they probably will have to send their child to a residential school at a much earlier age than they would normally contemplate. If cochlear implants in the first year of life present a risk-free alternative, it seems unrealistic to expect parents to choose this enormous burden for reasons unrelated to the welfare of their child. (Especially since, as the authors suggest, it is not wrong to seek to cure such deafness-causing diseases as meningitis even if doing so will reduce the DEAF population.) Furthermore, hearing parents might plausibly worry that they will not be successful in 
raising a happy and productive DEAF or deaf child; how much simpler, then, from the perspective of the child's own well-being, to choose the implants.

Second, as the authors point out, there are many more "deaf" people than there are "DEAF" people since many "visual" people fail to become successful members of the DEAF-WORLD or choose not to do so. Thus, there is no certainty, perhaps not even a likelihood, that the child in question will make that step, and without that likelihood all of the arguments about not diminishing minority cultures fall flat.

Third, against the authors' positive depiction of the DEAF-WORLD, one needs to think seriously about the limited opportunities that exist for even the most positively acculturated DEAF person. Marriage partners, conversation partners, vocations, and avocations are severely limited. Yes, one can think of cultural minorities about whom the same could be saide.g., the Amish or very Orthodox Jews-but these children can change their minds as adults and a significant percentage do so. As I have argued elsewhere, every child has a "right to an open future" (Davis 1997; the concept is Joel Feinberg's) in which she can choose her mate, her vocation, her religion, her reading material, her place of residence, and so forth. Because deafness severely limits the child's future in an irrevocable fashion, I cannot agree that parents act wrongly in "curing” a child's deafness. ${ }^{1}$ Furthermore, if deafness is not a culture but a disability, then the authors' claim becomes even harder to sustain, even if that disability were the entry ticket to a rich and happy culture.

Against these arguments, the authors suggest that the parents of a deaf child have a special connection to the DEAF-WORLD, which grounds a unique obligation to be concerned for the continuing strength and flourishing of the DEAF population. They suggest that this special concern may be powerful enough to tip the balance when parents are weighing their obligations to the child's best interest against their moral concern for the flourishing of minority cultures. This suggestion seems false. We all have obligations to be concerned about the situation of vulnerable minorities. Those of us in the majority group who have family members in the minority population arguably have a special awareness of the minority situation, but not therefore a unique obligation. It is not, after all, considered a valid moral argument to say, "Why should I care about the flourishing of the DEAF population? No one in my family is DEAF!" Some years ago, when my only child was quite young, I would occasionally-mostly to be pro- 
vocative-respond to persons who questioned my active commitment to gay rights by saying that, after all, my son had approximately a 10 percent chance of turning out to be gay, and I needed to enhance his chances of having a just and pro-gay society to live in. But in retrospect, that seems nonsensical; now that my child has turned out to be heterosexual, I certainly do not think that I have any less reason to continue my work for gay rights.

In conclusion, I cannot accept the foundational claim that deafness is primarily to be understood as (potential) membership in a cultural and linguistic minority, rather than as a disability. But even if I were to be persuaded to that claim, I do not agree that the needs of that culture for continuing population strength trump a hearing family's plausible assumption that by giving their baby normal hearing, they have increased her chances for a happy life and also for a much more open future.

Like the authors, I end with more questions. By limiting myself to Lane and Grodin's challenge, I have made only a very narrow claim: that hearing parents do not act wrongly when they choose (safe and effective) cochlear implants for a deaf baby. Questions abound for future dialogue: Do hearing parents therefore act wrongly if they decide against implants? Ought this to be considered neglect and grounds for the state to step in and insist on implants? What about parents who are deaf or DEAF? Is it wrong for them to choose implants for their children? Wrong for them to refuse implants? Wrong for them to seek genetic counseling to maximize their chances of having deaf children? Wrong for them deliberately to expose themselves to rubella, for example, in order to change a hearing fetus to a deaf one? If we accept the disability premise, these will be tough questions with which to grapple.

The author of this article is hearing.

\section{NOTE}

1. Lane and Grodin note that most DEAF adults are opposed to the notion of cochlear implants and infer from that that DEAF children would refuse implant surgery if they were old enough to be consulted. But, of course, in my view, children are not born DEAF, merely deaf. Further, it makes as much sense to ask ordinary hearing people now if they would have wanted implants had they been born deaf as it does to ask DEAF people that question. 


\section{KENNEDY INSTITUTE OF ETHICS JOURNAL - SEPTEMBER I997}

\section{REFERENCES}

Cohen, Leah. 1995. Train Go Sorry: Inside a Deaf World. Boston: Houghton Mifflin.

Davis, Dena S. 1997. Genetic Dilemmas and the Child's Right to an Open Future. Hastings Center Report 27 (2):7-15.

Lane, Harlan, and Grodin, Michael. 1997. Ethical Issues in Cochlear Implant Surgery: An Exploration into Disease, Disability, and the Best Interests of the Child. Kennedy Institute of Ethics Journal 7: 231-51. 